\title{
ANALISIS SISTEM PAKAR DIAGNOSA HAMA DAN PENYAKIT PADA TANAMAN PINANG MENGGUNAKAN METODE FORWARD CHAINNING
}

\author{
Rosmaneli \\ Program Studi Sistem Informasi, Fakultas Teknik dan Ilmu Komputer, Universitas Islam Indragiri \\ Email: rosmaneli0011@gmail.com (korespondensi)
}

\begin{abstract}
The presentation of information is growing rapidly over time. Starting from text, voice, images and videos. It continues to grow and is influenced by improvements in information presentation technology. The computers as an information technology are often used as human intermediaries for an information system. This is evidenced by the emergence of various systems related to computers as data processing. One application is the Expert System.
\end{abstract}

Keywords: Expert system, pests, diseases, areca nut, forward chainning.

\begin{abstract}
Abstrak
Penyajian informasi yang semakin berkembang pesat dari waktu kewaktu. Dimulai dari teks, suara, gambar dan video. Hal ini terus berkembang dan ikut terpengaruh dengan peningkatan teknologi penyajian informasi. Komputer sebagai salah satu dari teknologi infromasi, sering dijadikan perantara manusia terhadap suatu sistem informasi. Ini dibuktikan dengan bermunculannya berbagai sistem yang berkaitan dengan komputer sebagai pengolah data. Salah satu penerapannya adalah Sistem Pakar.
\end{abstract}

Kata kunci: Sistem pakar, hama, penyakit, pinang, forward chainning.

\section{Pendahuluan}

Penyajian informasi yang semakin berkembang pesat dari waktu kewaktu. Dimulai dari teks, suara, gambar dan video. $\mathrm{Hal}$ ini terus berkembang dan ikut terpengaruh dengan peningkatan teknologi penyajian informasi. Komputer sebagai salah satu dari teknologi infromasi, sering dijadikan perantara manusia terhadap suatu sistem informasi. Ini dibuktikan dengan bermunculannya berbagai sistem yang berkaitan dengan komputer sebagai pengolah data. Salah satu penerapannya adalah Sistem Pakar.

Sistem pakar adalah sistem informasi berbasis komputer yang menggunakan pengetahuan pakar untuk mencapai performa keputusan tingkat tinggi dalam domain persoalan sempit, (Turban, 2001). Sistem Pakar adalah sebuah sistem yang menggunakan pengetahuan manusia dimana pengetahuan tersebut dimasukkan kedalam sebuah komputer dan kemudian digunakan untuk menyelesaikan masalah-masalah yang biasanya membutuhkan kepakaran atau keahlian manusia. Sampai saat ini sudah ada beberapa hasil perkembangan sistem pakar dalam berbagai bidang sesuai dengan kepakaran seseorang misalnya bidang kedokteran, pertanian, dan pendidikan.

Indonesia kaya akan beragam jenis tanaman, salah satunya adalah pinang, pinang merupakan salah satu tanaman yang banyak dibudidayakan oleh masyarakat Inhil sebagai mata pencarian. Pinang mempunyai nilai ekonomis yang cukup baik dengan manfaat yang beragam dan daerah penyebarannya cukup luas. Manfaat biji pinang antara lain untuk bahan industri seperti tekstil, zat pewarna, kosmestik, minuman dan farmasi, disamping itu sebagai bahan makanan stimulasia dan bumbu masak. Daun dari pinang juga dapat digunakan sebai obat gangguan saluran pernafasan. Batang digunakan untuk bahan bangunan, saluran air dan sering dipakai sebagai perlombaan panjat pinang dalam rangka memperingati hari-hari berasar. Akar dimanfaatkan untuk obat cacing dan ganguan pencernaan.

Salah satu faktor rendahnya perkembangan dan produkrifitas tanaman pinang kerena kurangnya pengetahuan dan informasi yang dimiliki para pembudidaya 
dan masyarakat mengenai hama dan penyakit yang menyerang tanaman pinang serta cara mengatasinya. Keterbatasan waktu dan minimnya pakar dalam hal tersebut menjadi sebuah kendala dalam pembudidayaan tanaman pinang. Untuk mengatasi permasalahan tersebut, dibutuhkan suatu sistem yang dapat membantu pihak-pihak yang terlibat dalam upaya budidaya tanaman pinang, dengan menerapkan salah satu metode yang dapat mengadopsi pengetahuan pakar kedalam komputer sehingga komputer dapat menyelesaikan masalah seperti layaknya seorang pakar.

Dengan adanya sistem ini diharapkan dapat membantu pembudidaya tanaman pinang dan masyarakat yang melakukan upaya budidaya tanaman pinang dalam menditeksi hama dan penyakit yang menyerang tanaman pinang melalui gejala fisik yang terjadi serta mengetahui solusi atau cara menanggulangi hama dan penyakit tersebut. Berdasarkan permasalahan yang terjadi, maka dilakukan penelitian dengan mengangkat tema "Sistem pakar diagnosa hama dan penyakit pada tanaman pinang dengan metode forward chaining" yang dapat menjadi bekal pengetahuan dan petunjuk bagi para pembudidaya tanaman pinang dan masyarakat dalam merawat tanaman pinang.

\subsection{Perumusan Masalah}

Berdasarkan latar belakang diatas maka dapat ditarik suatu rumasan masalah sebagai berikut :

1. Sulitnya mengetahui jenis hama dan penyakit yang menyerang tanaman pinang karena kurangnya pengetahuan pembudidaya dan masyarakat terhadap jenis hama dan penyakit pada tanaman pinang.

2. Waktu yang dibutuhkan untuk mengetahui hama dan penyakit pada tanaman pinang cukup lama karena kurangnya penyuluhan yang mengatasi masalah tersebut sehingga dibutuhkan suatu aplikasi yang dapat melakukan diagnosa hama dan penyakit secara cepat.

\subsection{Tujuan Penelitian}

Tujuan dari penelitian ini adalah :

1. Untuk menyediakan suatu sistem aplikasi yang dapat membantu pihak pembudidaya tanaman pinang.

2. Untuk membantu pembudidaya tanaman pinang dan masyarakat yang melakukan upaya budidaya tanaman pinang dalam mendeteksi hama dan penyakit yang menyerang tanaman pinang.

\subsection{Metodologi Penelitian}

Dalam penelitian ini ada beberapa metode yang digunakan antara lain : 1. Penelitian Lapangan (Field Research) a. Pengamatan lansung (Observasi)

Dalam penelitian ini dilakukan pengamatan secara terang-terangan dan berpartisipasi dalam jangka waktu tertentu.

b. Wawancara (Interview)

Merupakan suatu cara pengumpulan data dengan menggunakan tanya jawab secara lansung dengan pihakpihak yang bersangkutan dalam bidang yang diteliti untuk memperoleh informasi yang dibutuhkan.

2. Riset Perpustakaan (Library Research) Metode ini merupakan cara yang dilakukan dengan pencarian buku-buku yang ada hubungannya dengan penelitian yang dilaksanakan sebagai pedoman dalam perpustakaan.

\section{LANDASAN TEORI}

\subsection{Sistem Pakar (Expert System)}

Expert System (ES) mulai dikembangkan pada pertengahan tahun 1960-an oleh Artificial Intelligence Corporation. Periode penelitian Artificial Intelligence ini didominasi oleh suatu keyakinan bahwa nalar yang di gabung dengan komputer canggih akan menghasilkan prestasi pakar atau bahkan manusia super. Suatu usaha kearah ini adalah General Purpose ProblemSolver (GPS). GPS sendiri merupakan sebuah Predecessor menuju Expert System (ES). GPS berusaha untuk menyusun langkah-langkah yang dibutuhkan untuk mengubah situasi awal menjadi atau tujuan yang telah ditentukan sebelumnya (Kusrini, 2006).

Sistem pakar adalah sebuah sistem yang menggunakan pengetahuan manusia dimana pengetahuan tersebut dimasukkan ke dalam sebuah komputer dan kemudian digunakan untuk menyelesaikan masalah-masalah yang biasanya membutuhkan kepakaran atau keahlian manusia (Turban, 2001).

Sistem pakar adalah program komputer yang mempresentasikan dan melakukan penalaran dengan pengetahuan beberapa pakar untuk memecahkan masalah atau memberikan saran (Jackson, 1999).

Sistem pakar adalah program yang berbasiskan pengetahuan yang menyediakan solusi "kualitas pakar" kepada masalah-masalah dalam bidang (domain) yang spesifik (Luger dan Stubblefield, 1993).

Sistem pakar (Expert System) adalah program komputer yang merupakan cabang dari ilmu komputer yang disebut Artificial Intellegence (AI). Tujuan ilmu Artificial Intelegence adalah membuat sesuatu menjadi cerdas dalam hal pemahaman 
melalui program komputer yang ditunjukkan dengan tingkah laku cerdas. Sistem pakar merupakan sistem yang berbasis pengetahuan, yaitu sistem yang meniru penalaran dari seorang pakar dalam bidang tertentu. Sistem ini menggunakan pengetahuan manusia untuk menyelesaikan masalah yang biasanya memerlukan kepakaran seorang ahli (Paulus, 2013)

Sistem pakar, yang mencoba memecahkan masalah yang biasanya hanya bisa di pecahkan oleh seorang pakar, dipandang berhasil ketika mampu mengambil keputusan sepeti yang dilakukan oleh pakar aslinya baik di sisi proses pengambilan keputusanya maupun hasil keputusan yang diperoleh.

Sebuah sistem pakar memiliki 2 komponen utama yaitu basis pengetahuan dan mesin inferensi. Basis pengetahuan merupakan tempat penyimpanan pengetahuan dalam memori komputer, dimana pengetahuan ini diambil dari pengetahuan pakar (Kusrini, 2008).

Komponen-komponen sistem pakar adalah sebagai berikut :

a. Akuisi Pengetahuan (Knowledge Base)

b. Basis Pengetahuan (Data Base)

c. Mesin Inferensi (Inference Engine)

d. Antar muka Pengguna (User Interface)

\subsection{Tanaman Pinang}

Tanaman pinang (Areca catechu L) merupakan tanaman liar, berupa palem, buah pinang berasal dari Tawangmangu. Tinggi sampai $20 \mathrm{~m}$, biasanya tumbuh ditepi sungai dan pekarangan, sampai ketinggian $1400 \mathrm{~m}$ dpl. Daun bersirip genap, bunganya tongkol bercabang, buah berbentuk kerucut, berkulit tebal dan berbiji bulat. Tumbuhan ini bijinya mengandung lemak, angkloid dan tannin. Secara tradisional biji pinang dapat digunakan untuk obat pendarahan antara lain untuk menghentikan cucur darah, dan sebagai obat luka.

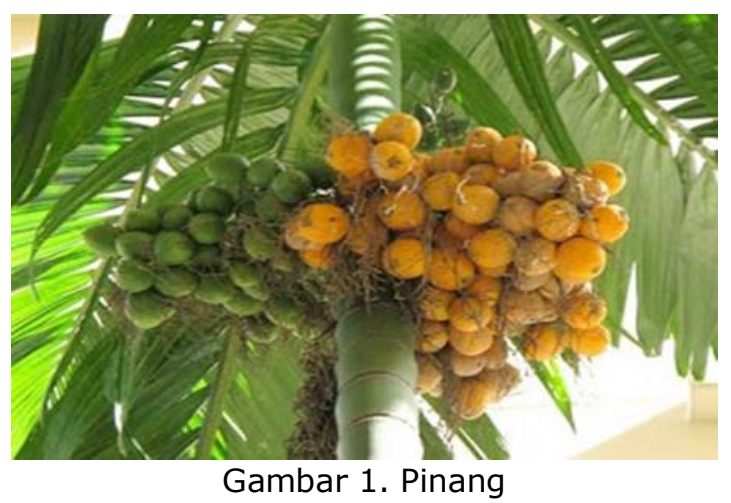

\subsection{Hama dan Penyakit Tanaman} Pinang

Berikut ini adalah beberapa contoh dari pada penyakit dan hama tanaman pinang

1. Bercak daun menguning (yellow leaf spot) Penyababnya penyakit bercak daun adalah cendawan Curbularia sp. Gejala pada lamina daun, terlihat bercak-bercak kuning 3-10 mm diameter. Infeksi lanjut dapat menyebabkan kematian bibit. Penyemprotan dengan Dithane dapat mengurangi serangan.

2. (Leaf blight) Penyebabnya adalah Pestalotia palmarum Cooke. Gejala penyakit berupa bercak-bercak coklat kekuningan pada helaian daun. Pemupukan N dan K2O ataupun dengan pemberian naungan dapat menekan penyakit.

3. Karat merah daun (red rust) Penyebabnya yaitu Cephaleuros sp. Cendawan ini menginfeksi batang dan daun. Sehingga terlihat bercak tak beraturan pada bagian batang dan daun yang berwarna kekuningan. Untuk menghindari perlu dibuat naungan secukupnya.

4. Busuk akar/pangkal batang (root/collar rot)Penyebabnya adalah cendawan Fusarium sp. Dan Rhizoctoria sp. Penyakit ini biasanya terlihat di pembibitan dengan sistem drainase jelek. Serangan cendawan ini mengakibatkan tanaman layu.

5. Busuk buah (fruit rot) Penyebabnya adalah Phytopthora arecae. Gejala bercak basah terlihat pada permukaan buah dekat kelopak bunga (perianth). Bercak ini akan menyebar sehingga warna buah berubah menjadi hijau tua. Jika bercak mencapai bagian apikal buah maka akan menyebabkan buah gugur. Pengendalian secara kimia dapat di lakukan dengan fungisida Copper oxychlorride serta fitosanitasi (pembersihan) kebun. Pengendalian lainnya dengan melakukan fotosanitasi pada kebun-kebun.

6. Busuk pucuk (Bud rof) Penyebabnya sama dengan penyakit busuk buah. Yaitu P. Arecal. Bagian yang diserang adalah pangkal spidel pangkal spindle berwarna berangsur bagian yang terinfeksi serangan berat menyebabkan kuning coklat pucuk membusuk dengan bau khas. Pembersihan lokasi pertanaman dari tanaman terserang akan mencegah penyebaran penyakit.

7. Daun menguning (Yellow leaf disease) Penyebabnya adalah mycoplasm like 
organism (MLO). Daun yang terserang memperlihatkan warna kekuningan dan terdapat garis-garis nekrotik. Pada lamina daun. Pertumbuhan daun akan mengecil sehingga produksi buah menurun. Daging buah berwarna kehitaman. Pengendalian dengan cara terpadu dengan pemupukan, penggunaan fungisida $2 \mathrm{~g}$ phorate granula per pohon serta fitosanitasi.

8. (Busuk kaki) Penyebabnya adalah Ganoderma lucidum. Munculnya penyakit ini karena kurang pemeliharaan kebun, drainase jelek. Tanaman yang terserang menunjukan gejala kekeringan dimana daun menguning, terkulai dan akhirnya patah. Infeksi lanjut yaitu batang terlihat bercak coklat tidak beraturan dan mengeluarkan cairan. Akar tanaman akan membusuk. Untuk menghindari perlu pengaturan sistim drainase, kebersihan kebun. Bebeberapa mikroorganisme antagonis seperti Trichoderma sp, Streptomyces sp. dapat menjadi agen hayati pengendalian penyakit ini.

9. (Die back pembungaan dan gugur buah) Cooletotrichum gloesporioides berasosiasi dengan penyakit ini. Gejalanya terlihat tulang daun menguning dan terlihat mengering mulai ujung daun sampai ke arah pangkal. Bunga betina akan gugur. Faktor lainnya yang menyebabkan gugur buah adalah kegagalan polinasi, kandungan unsur hara kurang, cekaman air dan temperatur atupun faktor fisiologis. Pengendalian dengan fungisida dithane $4 \mathrm{~g} / \mathrm{L}$ air pada 2 tahap yaitu dilakukan pada saat bunga betina terbuka dan pada 20-24 hari berikutnya.

10. (Bacterial leaf stripe) Penyebab yaitu Xanthomonas campestris pv. Arecae. Gejala daun terlihat bercak-bercak selebar $0.5-1.0 \mathrm{~cm}$. Permukaan bagian bawah daun ditutupi oleh bakteri. Daun yang terserang menimbulkan bercak yang tidak teratur berwarna putih keabuan atau kekuningan. Penyemprotan dengan antibiotik tetracyclin $1 \mathrm{~g} / 2 \mathrm{~L}$ air yang dilakukan setiap 2 minggu.

11. (Mengecil (Band) Penyebab penyakit ini belum diketahui. Gejalanya yaitu daun menjadi pendek, mengecil dan berbentuk sapu. Warna daun menjadi hijau tua, batang meruncing dan jarak antar ruas batang memendek. Mahkota pohon bentuk seperti berbunga mawar, sehingga pembungaan menjadi tidak sempurna, dan produksi buah menurun. Pengendalian penyakit dilakukan dengan perbaikan drainase, penggemburan tanah. Pemberian campuran Copper sulfat dengan kapur perbandingan 1 : 1 dengan dosis $225 \mathrm{~g}$ per pohon per 6 bulan dapat memperbaiki kondisi lingkungan tumbuh.

12. Batang berdarah (Stem bleeding) Penyebabnya adalah Thielaviopsis paradoxa Von Hohn (Ceralostomelia paradoxa). Terjadi perobahan warna pada bagian yang terinfeksi di bagian batang dan jaringan lembut serta mengeluarkan cairan berwarna coklat gelap. Dugaan bahwa penyakit in berkembang akibat air tanah yang dangkal dan drainase jelek. Untuk menghindari serangan hama Xyleborus sp. Yang dapat masuk melalui lobang tersebut dilakukan penempelan dengan tar dan insektisida.

13. Buah retak (Nut splitting) Penyebabnya karena ketidak seimbangan fisiologis. Karakteristik penyakit ini terlihat dari buah pinang yang retak-retak. Gejala yang dimulai dengan buah kekuningan ketika buah setengah matang atau tiga per empat bagian matang. Perbaikan drainase dan penyemprotan dengan Borax $2 \mathrm{~g} / 1$ I air pada tahap awal dapat menekan serangan penyakit.

\subsection{Perangkat Lunak yang digunakan}

Adapun perangkat lunak yang digunakan dalam penelitian ini yaitu pemograman Visual Basic 6.0 dan basis data Microsof Acsess 2007.

\subsubsection{Microsof visual Basic 6.0}

Microsof visual Basic pada dasarnya adalah bahasa pemograman komputer. Bahasa pemograman adalah perintah perintah atau instruksi yang dimengerti oleh komputer untuk melakukan tugas tugas tertentu. Bahasa pemograman Microsof visual basic merupakan bahasa yang mudah dipahami sehingga manusia sekarang lebih banyak memilih pemograman visual basic.

\subsubsection{Microsoft Access 2007}

Menurut Andi (2007), Database adalah kumpulan data yang dapat digambarkan sebagai aktivitas dari satu atau lebih organisasi yang berelasi. Sedangkan Database manajemen sistem adalah perangkat lunak yang didesain untuk membantu dalam hal pemeliharaan dan utilitas kumpulan data dalam jumlah besar. 
Database adalah sekumpulan Data Store (bisa dalam jumlah yang sangat besar) yang tersimpan dalam Magnetik Disk, Optical Disk, Magnetic Drum atau media penyimpanan sekunder lainnya (Ladjamudin 2005). Untuk membangun sebuah Database diperlukan aplikasi pembangun atau pembuat Database seperti Mysql, Ms. Access 2007 dan banyak lagi yang lain, dalam hal ini penulis menggunakan Microsoft Access 2007 untuk membangun Database yang nantinya akan membantu kinerja dari sistem yang akan dibuat.

\section{ANALISA DAN PERANCANGAN}

\subsection{Analisa Sistem}

Tahapan analisa sistem dilakukan setelah tahapan perencanaan sistem dan sebelum tahapan desain sistem. Tahapan analisa sistem merupakan tahapan yang kritis dan sangat penting karena kesalahan ditahap ini akan menyebabkan kesalahan ditahap selanjutnya. Tahapan ini digunakan untuk medefinisikan semua kebutuhan pemakai dan meletakan dasar-dasar untuk proses perancangan sistem.

\subsection{Analisis Masalah}

Indonesia kaya akan beragam jenis tanaman, salah satunya adalah pinang, pinang merupakan salah satu tanaman yang benyak dibudidayakan oleh masyarakat Inhil sebagai mata pencarian. Pinang mempunyai nilai ekonomis yang cukup baik dengan manfaat yang beragam dan daerah penyebarannya cukup luas. Manfaat biji pinang antara lain untuk bahan industr seperti tekstil, zat pewarna, kosmetik, minuman dan farmasi, disamping itu sebagai bahan makanan stimulasi dan bumbu masak. Daun dari pinang juga dapat digunakan sebagai obat gangguan saluran pernafasan. Batang pinang dapat digunakan untuk bahan bangunan, saluran air dan sering dipakai sebagai perlombaan panjat pinang dalam rangka memperingati hari-hari besar. Akar dimanfaatkan untuk obat cacing dan gangguan pencernaan.

Salah satu fakor rendahnya perkembangan dan produktifitas tanaman pinang karena kurangnya pengatahuan dan informasi yang dimiliki para pembudidaya dan masyarakat mengenai hama dan penyakit yang menyerang tanaman pinang serta cara mengatasinya. Keterbatasan waktu dan minimnya pakar dalam hal tersebut menjadi sebuah kendala dalam pembudidayaan tanaman pinang.

Untuk mengatasi permasalahan tersebut, dibutuhkan suatu sistem yang dapat membantu pihak-pihak yang terlibat dalam upaya budidaya tanaman pinang, dengan menerapkan salah satu metode yang dapat mengadopsi pengetahuan pakar kedalam komputer sehingga komputer dapat menyelesaikan masalah seperti layaknya seorang pakar.

\subsection{Analisa Kebutuhan}

Analisa kebutuhan dilakukan untuk membantu dalam merancang dan membangun sistem yang akan dibuat. kebutuhan yang diperlukan meliputi kebutuhan perangkat keras (hardware), kebutuhan perangkat lunak (software) dan kebutuhan brainware

Tabel 1 Hama dan Penyakit

\begin{tabular}{|c|l|}
\hline ID Penyakit & \multicolumn{1}{|c|}{ Penyakit } \\
\hline H1 & Rayap \\
\hline H2 & Belalang \\
\hline H3 & Kutu \\
\hline H4 & Kepik \\
\hline H5 & Ulat bunga \\
\hline H6 & Gugur buah muda \\
\hline H7 & Kumbang pinang \\
\hline P1 & Bercak daun menguning \\
\hline P2 & Karat merah daun \\
\hline P3 & Busuk pangkal batang \\
\hline P4 & Busuk buah \\
\hline P5 & Busuk pucuk \\
\hline P6 & Busuk akar \\
\hline P7 & Gugur bunga dan buah \\
\hline P8 & Tanaman kerdil \\
\hline
\end{tabular}

Tabel 2 Gejala

\begin{tabular}{|c|c|}
\hline $\begin{array}{c}\text { ID } \\
\text { Gejala }\end{array}$ & Gejala \\
\hline $\mathrm{G} 1$ & Pucuk layu \\
\hline $\mathrm{G} 2$ & Kemudian mati \\
\hline G3 & Daun berlubang \\
\hline G4 & $\begin{array}{l}\text { Daun berwarna kekuningan, coklat dan } \\
\text { akhirnya mengering }\end{array}$ \\
\hline G5 & Buah muda gugur \\
\hline G6 & Pertumbuhan tidak normal \\
\hline G7 & $\begin{array}{l}\text { Adanya garis-garis berwarna coklat tua } \\
\text { lama kelamaan mengering dan patah }\end{array}$ \\
\hline G8 & $\begin{array}{l}\text { Adanya telur ulat pada bagian seludang } \\
\text { pucuk, sehingga pucuk tidak dapat } \\
\text { membuka dengan sempurna }\end{array}$ \\
\hline G9 & $\begin{array}{l}\text { Buah pinang yang ditusuk akan berwarna } \\
\text { hitam pada permukaan kulit buah dan } \\
\text { daging buah berwarna coklat gelap. }\end{array}$ \\
\hline G10 & Buah gugur \\
\hline G11 & $\begin{array}{l}\text { Berlubang sampai bagian biji, diameter } \\
\text { lubang kira-kira } 0.6-1.0 \mathrm{~mm} \text {. }\end{array}$ \\
\hline G12 & $\begin{array}{l}\text { Gejala pada lamina daun, terlihat bercak- } \\
\text { bercak kuning 3-10 mm diameter }\end{array}$ \\
\hline G13 & Bibit mati \\
\hline G14 & $\begin{array}{l}\text { Terlihat bercak-bercak pada bagian } \\
\text { batang dan daun yang berwarna } \\
\text { kekuningan }\end{array}$ \\
\hline G15 & Tanaman layu \\
\hline G16 & $\begin{array}{l}\text { Gejala bercak basah terlihat pada } \\
\text { permukaan buah dekat kelopak bunga } \\
\text { (perianth) }\end{array}$ \\
\hline G17 & Warna buah menjadi hijau tua \\
\hline G18 & $\begin{array}{l}\text { Jika bercak ini mencapai bagian apikal } \\
\text { buah maka akan menyebabkan buah } \\
\text { gugur }\end{array}$ \\
\hline G19 & Bagian yang diserang adalah pangkal \\
\hline
\end{tabular}




\begin{tabular}{|c|c|}
\hline ID & Gejala \\
\hline & spindel \\
\hline G20 & $\begin{array}{l}\text { Pada bagian pangkal spindel berwarna } \\
\text { berangsur bagian yang terinfeksi serangan } \\
\text { berat menyebabkan kuning coklat pucuk } \\
\text { membusuk dengan bau khas }\end{array}$ \\
\hline G21 & Kekeringan \\
\hline G22 & $\begin{array}{l}\text { Daun menguning, tekulai dan akhirnya } \\
\text { patah }\end{array}$ \\
\hline G23 & $\begin{array}{lcc}\text { Batang terlihat bercak coklat tidak } \\
\text { beraturan dan mengeluarkan cairan }\end{array}$ \\
\hline G24 & Akar tanaman akan membusuk \\
\hline G25 & $\begin{array}{l}\text { Tulang daun menguning dan terlihat } \\
\text { mengering, mulai unjung daun sampai ke } \\
\text { arah pangkal }\end{array}$ \\
\hline G26 & Bunga betina gugur \\
\hline G27 & $\begin{array}{l}\text { Daun menjadi pendek, mengecil dan } \\
\text { berbentuk sapu }\end{array}$ \\
\hline G28 & Warna daun menjadi hijau tua \\
\hline G29 & $\begin{array}{l}\text { Batang meruncing dan jarak anta ruas } \\
\text { batang memendek }\end{array}$ \\
\hline G30 & $\begin{array}{l}\text { Mahkota pohon bentuk seperti berbunga } \\
\text { mawar, sehingga pembungaan menjadi } \\
\text { tidak sempurna, dan produksi buah } \\
\text { menurun }\end{array}$ \\
\hline
\end{tabular}

Pada tabel 3 Solusi dibawah ini mnejelaskan tentang solusi dan mengatasi dari pada hama dan penyakit tanaman pinang.

Tabel 3.6 Solusi

\begin{tabular}{|c|c|}
\hline $\begin{array}{l}\text { ID } \\
\text { Solusi }\end{array}$ & Solusi \\
\hline S1 & $\begin{array}{l}\text { Pengendalian rayap dapat dilakukan } \\
\text { dengan cara menutup bagian pangkal } \\
\text { batang dengan pasir ataupun secara } \\
\text { kimiawi dapat menggunakan insektisida } \\
\text { aldrin }\end{array}$ \\
\hline S2 & $\begin{array}{l}\text { Pengendalian secara kimiawi dapat } \\
\text { menggunakan insektisida aldirin, diazinon }\end{array}$ \\
\hline S3 & $\begin{array}{l}\text { Pengendalian secara kimiawi dapat } \\
\text { menggunakan insektisida }\end{array}$ \\
\hline S4 & $\begin{array}{l}\text { Pengendalian dilakukan dengan insektisida } \\
\text { sitemik sevin } 4 \mathrm{G} \text { dengan dosis } 10 \mathrm{~g} \text { per } \\
\text { tanaman setiap } 3 \text { bulan. }\end{array}$ \\
\hline S5 & $\begin{array}{l}\text { Pengendalian secara kimiawi dapat } \\
\text { menggunakan insektisida }\end{array}$ \\
\hline S6 & $\begin{array}{l}\text { Pengendalian secara kimiawi dilakukan } \\
\text { dengan menyemprot endosulfan dan pada } \\
\text { tandan. }\end{array}$ \\
\hline S7 & 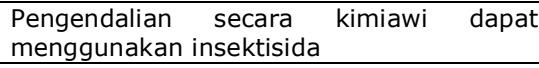 \\
\hline S8 & $\begin{array}{l}\text { Penyemprotan dengan dithane dapat } \\
\text { mengurangi serangan }\end{array}$ \\
\hline S9 & Untuk menghindari perlu dibuat naungan \\
\hline S10 & $\begin{array}{l}\text { Pencegahan penyakit ini dapt dilakukan } \\
\text { dengan memperbaiki sistem drainase pada } \\
\text { area pembibitan }\end{array}$ \\
\hline S11 & $\begin{array}{l}\text { Pengendalian secara kimia dapat dilakukan } \\
\text { dengan fungisida copper oxychlorride } \\
\text { serta fitosanitasi (pembersihan) kebun. } \\
\text { Pengendalian lainnya denga melakukan } \\
\text { fotosanitasi pada kebun-kebun. }\end{array}$ \\
\hline S12 & $\begin{array}{l}\text { Pembersihan lokasi } \begin{array}{l}\text { pertanaman dari } \\
\text { tanaman terserang akan mencegah } \\
\text { penyebaran penyakit }\end{array} \\
\end{array}$ \\
\hline S13 & $\begin{array}{l}\text { Untuk menghindari, perlu pengaturan } \\
\text { sitem drinase, kebersihan kebun. } \\
\text { Beberapa mikroorganisme antagonis } \\
\text { seperti trichoderma sp. Dapat menjadi } \\
\text { agen hayati pengendalian penyakit ini. }\end{array}$ \\
\hline S14 & $\begin{array}{l}\text { Pengendalian dengan fungisida dithane } 4 \\
\text { g/L air pada } 2 \text { tahap yaitu dilakukan pada } \\
\text { saat bunga betina terbuka dan pada } 20-24 \\
\text { hari berikutnya }\end{array}$ \\
\hline
\end{tabular}

S15 $\quad$ Pengendalian penyakit dilakukan dengan perbaikan drainase, penggemburan tanah

\section{IMPLEMENTASI DAN PENGUJIAN SISTEM}

\subsection{Implementasi}

\section{Antarmuka Login}

Rancangan

4.1.1 Halaman Menu Utama Login

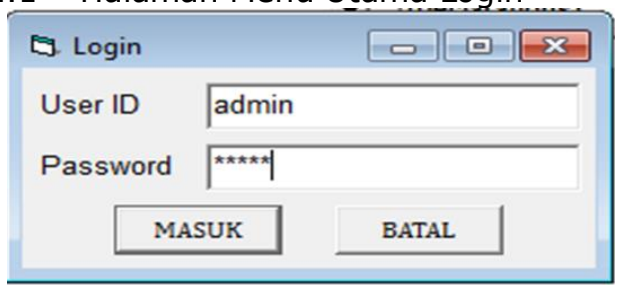

Gambar 2 Halaman Menu Utama Login.

Gambar 1 diatas merupakan from utama Login, jika diklik tombol User ID dan password dengan inputan nama admin dan kemudian klik masuk (input) untuk memulai awal pembukaan program aplikasi menu utama pakar.

\subsubsection{Menu utama pakar}

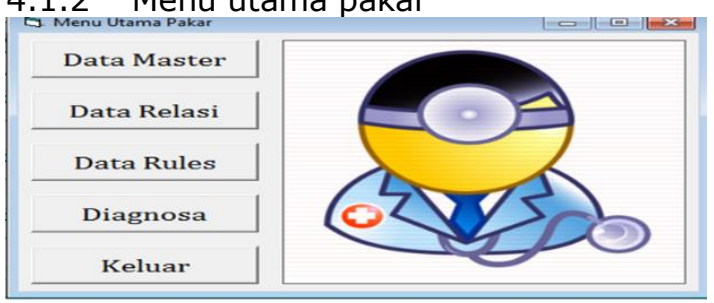

Gambar 3 Menu utama pakar.

Pada gambar 3 di atas from menu utama pakar kita klik secara berurutan untuk meliahat hasil menu-menu utama pakar.

\subsubsection{Data sub menu master}

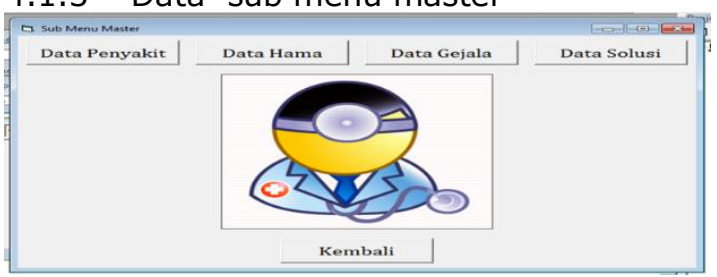

Gambar 4 Sub menu master.

Pada gambar 4 di atas from sub menu master, Tampilan awal klik kolom awal data penyakit untuk mengetahui data macammacam penyakit yang sudah tersimpan. Kemudian selanjutnya lakukan pencarian seperti yang sudah dijelaskan pertama.

\subsubsection{Data Penyakit}




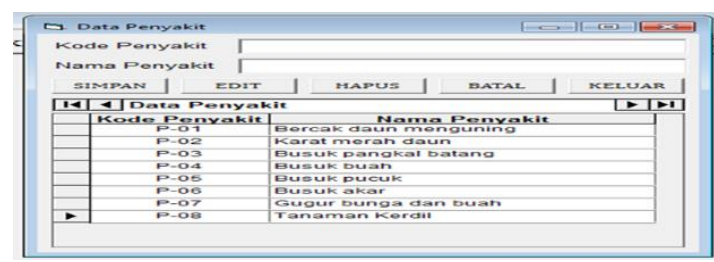

Gambar 5 : Data Penyakit

Pada gambar 5 di atas from data penyakit kolom data penyakit dijelaskan bahwa untuk mengedit, pertama kita lakukan untuk mengklik kolom kode penyakit dan nama penyakit yang akan diganti kode penyakit dan nama penyakit kemudian klik Edit kode dan nama penyakit kemudian klik simpan, maka akan tersimpan data penyakitnya. Jika ingin membatalkan editan, hapus, keluar serta penyimpannan klik tombol pada kolom yang sudah tertera dikolom bacaan hapus, batal dan keluar tersebut.

\subsubsection{Data Hama}

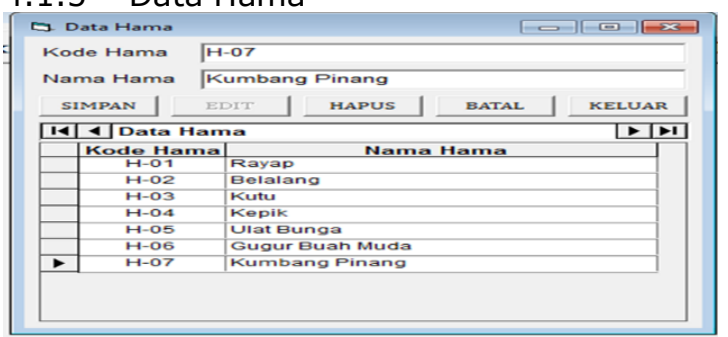

Gambar 6 Data Hama

Pada gambar 6 di atas from data hama kolom data hama dijelaskan bahwa untuk mengedit, pertama kita lakukan untuk mengklik kolom kode hama dan nama hama kemudian klik edit lalu hapus bagian kolom yang ada dan diganti kode hama dan nama hama kemudian simpan maka akan tersimpan data-data hama, Jika ingin menghapus atau batal serta keluar klik kolom yang sudah tertera bacaan hapus, batal serta keluar tersebut.

\subsubsection{Data Gejala}

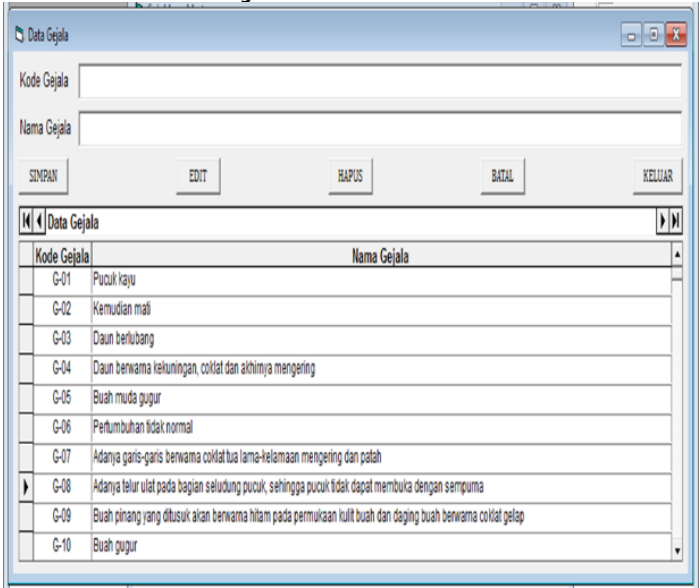

Gambar 7 Data Gejala
Pada gambar 7 di atas from data gejala, untuk penambahan data baru gejala dengan mengisi kolom kode gejala, nama gejala kemudian klik simpan, maka data baru akan tersimpan, begitu juga cara yang lain seperti hapus, edit, batal, keluar lakukan lah seperti langkah awal dengan memahami arti dari kata hapus, edit, batal, keluar. Maka semua akan terlihat akan hasil dari langkah-langkah yang dijalankan.

\subsubsection{Data Solusi}

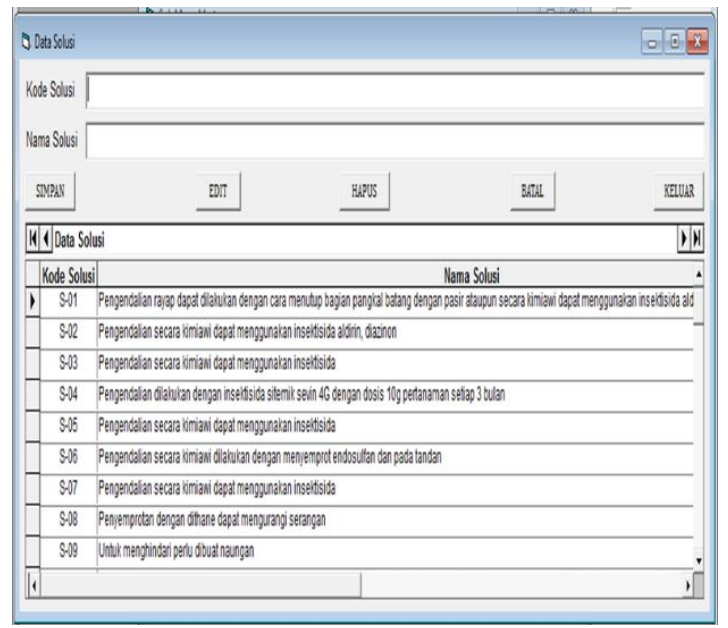

Gambar 8 Data solusi

Pada gambar 8 di atas from Data solusi, kolom data solusi dijelaskan bahwa untuk mengedit, pertama kita lakukan untuk meng klik kolom kode solusi dan nama solusi kemudian klik edit lalu hapus bagian kolom yang ada dan akan diganti kode solusi dan nama solusi kemudian simpan maka akan tersimpanlah data-data solusi, Jika ingin menghapus atau batal serta keluar klik kolom yang sudah tertera bacaan hapus, batal serta keluar tersebut.

\subsubsection{Data Relasi}

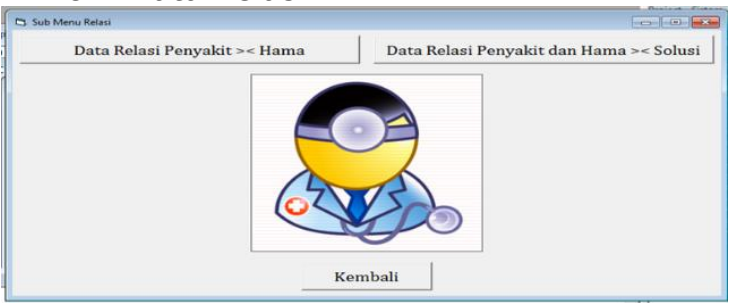

Gambar 9 Sub Menu Relasi

Pada gambar 9 di atas from sub menu master. Awal pertama dilakukan dengan meng klik Data relasi penyakit $><$ hama dan Data relasi penyakit dan hama $><$ solusi dimana didalam sistem tersebut terdapat data-data tentang penyakit dan hama beserta solusi.

\subsubsection{Data Relasi $><$ Hama}




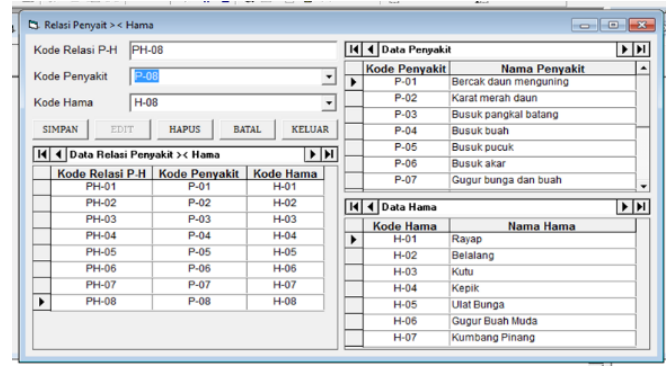

Gambar 10 Relasi Penyakit $><$ Hama

Pada gambar 10 di atas from Relasi Penyakit $><$ Hama, langkah awal yang dilakukan dengan menyimpan data relasi penyakit $><$ hama yang baru perlu di isi kolom kode relasi $\mathrm{PH}-\mathrm{S}$, kode relasi $\mathrm{P}-\mathrm{H}$, kode solusi kemudian klik simpan, maka data baru akan tersimpan, begitu juga cara yang lain seperti hapus, edit, batal, keluar lakukan lah seperti langkah awal dengan memahami arti dari kata hapus, edit, batal, keluar. Maka semua akan terlihat akan hasil dari langkah-langkah yang dijalankan.

\subsubsection{Data Relasi dan Hama $><$ Solusi}

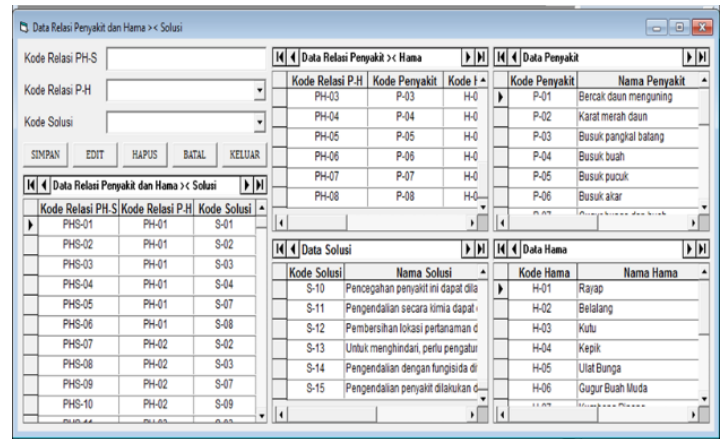

Gambar 11 : Data Relasi Penyakit dan Hama $><$ Solusi

Pada gambar 11 di atas from data relasi penyakit dan hama $><$ solusi, untuk penamabahan data dengan mengisi kolom kode Relasi PH-S, kode Relasi P-H, kode solusi kemudian klik simpan, maka data baru akan tersimpan, begitu juga cara yang lain seperti hapus, edit, batal, keluar lakukan lah seperti langkah awal dengan memahami arti dari kata hapus, edit, batal, keluar. Maka semua akan terlihat akan hasil dari langkah-langkah yang dijalankan.

\subsubsection{Data Rules}

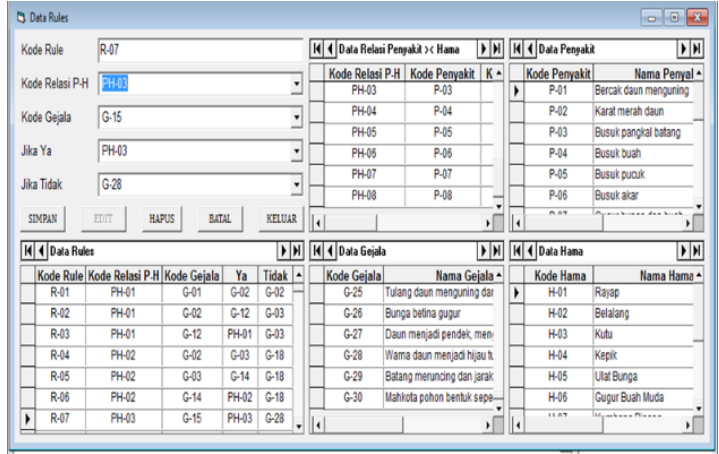

Gambar 12 Data Rules

Pada gambar 12 di atas from data rules untuk penambahan data rules yang baru dengan mengisi kolom kode Rule, kode relasi $\mathrm{P}-\mathrm{H}$, kode gejala, jika Ya atau Tidak. Kemudian klik simpan, maka data baru akan tersimpan, begitu juga cara yang lain seperti hapus, edit, batal, keluar lakukan lah seperti langkah awal dengan memahami arti dari kata hapus, edit, batal, keluar. Maka semua akan terlihat akan hasil dari langkah-langkah yang dijalankan.

\subsubsection{Data Diagnosa}

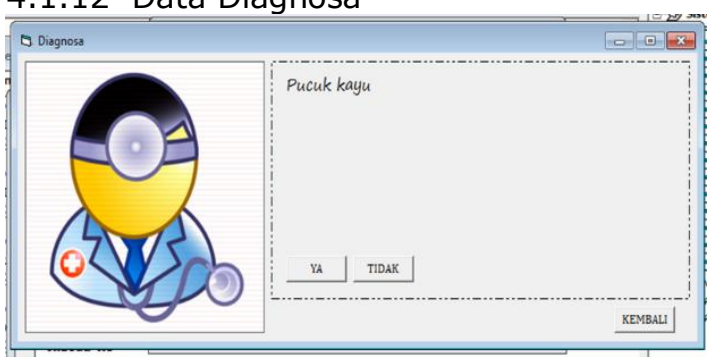

Gambar 13 Diagnosa

Pada gambar 13 di atas from Diagnosa. Langkah awal untuk mencari dan melanjutkan data hasil diagnosa hama dan penyakit dengan meng klik Ya atau tidak. Maka hasilnya akan terlihat.

\subsubsection{Data Diagnosa}

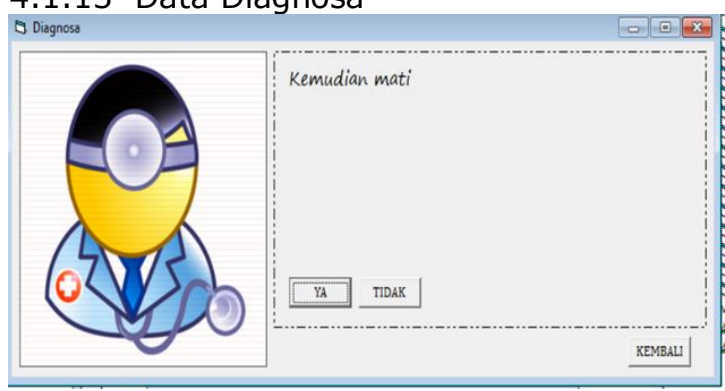

Gambar 14 Diagnosa

Pada gambar 14 diatas from Diagnosa. Langkah awal untuk mencari dan melanjutkan data hasil diagnosa hama dan penyakit dengan meng klik Ya atau tidak. Maka hasilnya akan terlihat. 
4.1.14 Data Hasil Diagnosa

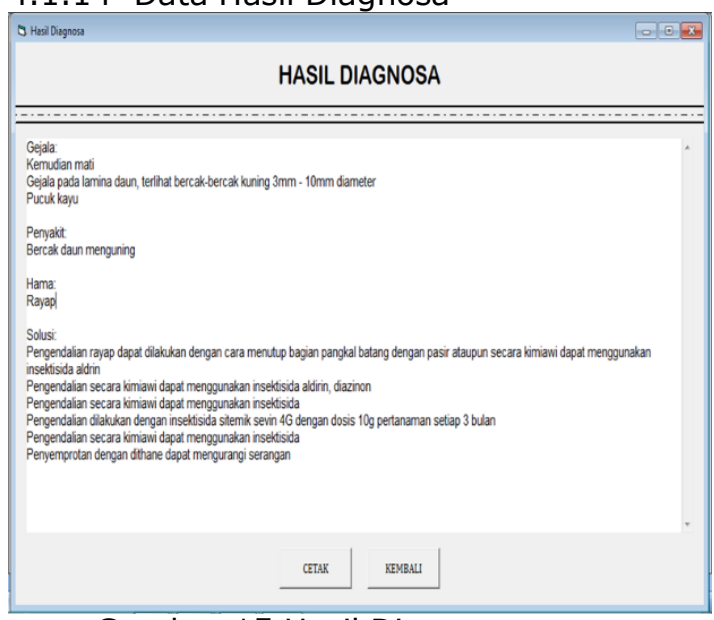

Gambar 15 Hasil Diagnosa

Pada gambar 15 Hasil diagnosa di atas merupakan from program sistem solusi hasil data akhir diagnosa hama dan penyakit yang menyerang tanaman pinang.

4.1.15 Data Sistem Pakar Diagnosa Hama dan Penyakit Pada Tanaman Pinang

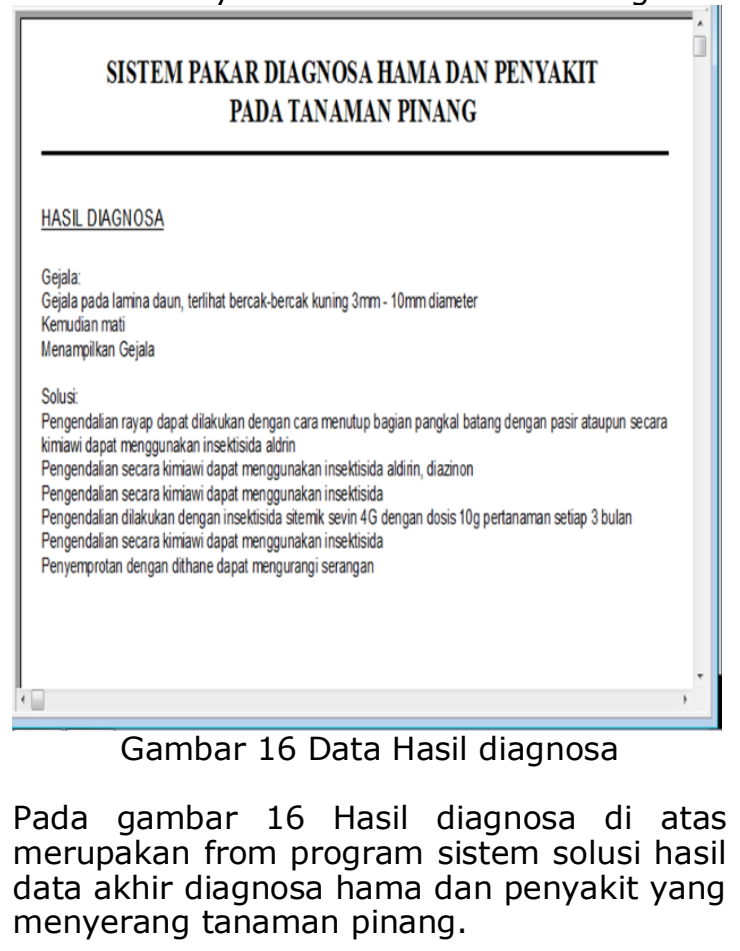

\section{KESIMPULAN DAN SARAN}

\subsection{Kesimpulan}

Dari hasil analisis yang dibuat, dapat disimpulkan sebagai berikut:

1. Dengan adanya system aplikasi ini maka diharapkan pihak pembudidaya pinang dapat terbantu.

2. Aplikasi ini akan membantu para pembudidaya dalam hal mendeteksi hama dan penyakit yang menyerang pinang.

\subsection{Saran}

Dalam tugas akhir ini agar dapat bermanfaat bagi para pembaca. Untuk dapat mengetahui dari pada informasi tananaman serta manfaat kinerja dari program aplikasi yaitu :

1. Menginformasikan betapa banyaknya manfaat pinang.

2. Sebagai bahan tempat penelitian bagi para pelajar serta mahasiswa.

3. Sebagai informasi bagai mana cara pembuatan lahan penanaman pinang.

4. Menginformasikan betapa mahalnya harga pinang.

5. Menginformasikan pembaca dapat mempelajari dan memahami rancangan pinyimpanan data menjadi sebuah listing program aplikasi.

6. Pengecekan laporan hasil diagnosa hama dan penyakit, gejala serta solusi dapat dilakukan secara efektif dan efesien.

\section{DAFTAR PUSTAKA}

[1] Al, Et Jaiswal, 2011. Tumbuhan Pinang (Area Catelu L).

[2] Crontquist, 1981. Klasifikasi Ilmiah Taman Nasional Alas Purwo, 2010. Sentra Informasi IPTEK, 2005.

[3] Hartati dan Ismawati 2008. Membangun Sistem Pakar.

[4] Hutapea, dan Syamsuhidayat 1991. Tanaman Pinang.

[5] Kusrini. 2006, dan Paulus. 2013. Sitem pakar Ekspert System (ES). Artifical Intelligence (AI). General Purpose Problem-Solver (GPS).

[6] Kristina dan Syahid 2007. Syarat Tumbuh Tanaman Pinang.

[7] Paulus, 2013. Sistem Pakar. (Ekspert System)

[8] Suriawiria, Unus H. Prof. Pakar Bioteknologi dan Agroindustri dari institut Teknologi Bandung.

[9] Sutojo, 2010. Kemampuan Menjelaskan (Explanation Capability).

[10] Tegarden, Wixsom, Dennis, 2009. UML (Unified Modelling Languange) Kata Pengantar.

[11] Wilson. 1998. Runut Maju (Forward Chainning) 